Ambiente \& Água - An Interdisciplinary Journal of Applied Science
ISSN 1980-993X - doi:10.4136/1980-993X
www.ambi-agua.net
E-mail: ambi.agua@gmail.com

\title{
Evaluation of water resource preservation areas in the Hydrographical Basin of Andreas Stream, RS, Brazil, using environmental monitoring programs
}

\author{
ARTICLES doi:10.4136/ambi-agua.2307 \\ Received: 26 Jul. 2018; Accepted: 11 Jan. 2019 \\ Rodrigo Augusto Klamt ${ }^{1 *}$; Eduardo Alexis Lobo $^{2}$ (D); \\ Adilson Ben da Costa ${ }^{2}$; Dionei Minuzzi Delevati ${ }^{3}$ \\ ${ }^{1}$ Universidade de Santa Cruz do Sul (UNISC), Santa Cruz do Sul, RS, Brasil \\ Programa de Pós-Graduação em Tecnologia Ambiental (PPGTA). E-mail: rodrigoklamt@ hotmail.com \\ ${ }^{2}$ Universidade de Santa Cruz do Sul (UNISC), Santa Cruz do Sul, RS, Brasil \\ Departamento de Biologia e Farmácia. Programa de Pós-Graduação em Tecnologia Ambiental (PPGTA). \\ E-mail: lobo@unisc.br, adilson@unisc.br \\ ${ }^{3}$ Universidade de Santa Cruz do Sul (UNISC), Santa Cruz do Sul, RS, Brasil \\ Departamento de Engenharia e Ciência Agrárias. \\ Programa de Pós-Graduação em Tecnologia Ambiental (PPGTA). E-mail: dionei@unisc.br \\ *Corresponding author
}

\begin{abstract}
This research evaluated the effectiveness of the implementation of water resource preservation areas in the Hydrographical Basin of Andreas Stream, county of Vera Cruz, RS, Brazil, established through Payment for Environmental Services (PES), using an environmental monitoring program to assess physical, chemical and microbiological variables. The PES is linked to the "Water Guardian" project, which aims to ensure the preservation of water resources by paying farmers for providing the environmental services to protect the springs and riparian areas that lie within their properties. Twenty sampling stations were selected for collecting water samples monthly during the period July 2012 to June 2014 (460 samples) to evaluate the following variables: water temperature, $\mathrm{pH}$, turbidity, dissolved oxygen, biochemical oxygen demand, nitrate, ammonia nitrogen, phosphate, total dissolved solids and thermotolerant coliforms. The evaluation was made based on decree 357/2005 of the National Environmental Council (CONAMA) and by applying the Water Quality Index (WQI). The results indicated a significant improvement in the water quality when comparisons were made between the periods before and after the installation of the preservation areas. The sampling points classified as "good" (CONAMA and WQI), which indicates water of good quality that is appropriate for multiple uses, increased from $52.0 \%$ to $72.0 \%$. In this sense, promoting the preservation of headwaters and riparian zones becomes of fundamental importance and highlights the role of PES as an operational tool for water resource preservation.
\end{abstract}

Keywords: hydrographical Basin of Andreas Stream, payment for environmental services (PES), water quality. 


\section{Avaliação de áreas de preservação de recursos hídricos na Bacia Hidrográfica do Arroio Andreas, RS, utilizando programas de monitoramento ambiental}

\section{RESUMO}

A presente pesquisa objetivou avaliar a efetividade da implantação de áreas de preservação de recursos hídricos na Bacia Hidrográfica do Arroio Andreas, município de Vera Cruz, RS, estabelecida através do Pagamento por Serviços Ambientais (PSA), utilizando um programa de monitoramento ambiental para avaliar variáveis físicas, químicas e microbiológicas. O PES está vinculado ao projeto "Guardião da Água", que visa garantir a preservação dos recursos hídricos, pagando aos agricultores a prestação de serviços ambientais para proteger as nascentes e áreas ribeirinhas que se encontram dentro de suas propriedades. Vinte estações de amostragem foram selecionadas para coleta mensal de amostras de água no período de julho de 2012 a junho de 2014 (460 amostras) para avaliar as seguintes variáveis: temperatura da água, $\mathrm{pH}$, turbidez, oxigênio dissolvido, demanda bioquímica de oxigênio, nitrato, nitrogênio amoniacal, fosfato total sólidos dissolvidos e coliformes termotolerantes. A avaliação foi feita com base no decreto 357/2005 do Conselho Nacional do Meio Ambiente (CONAMA) e na aplicação do Índice de Qualidade da Água (IQA). Os resultados indicaram uma melhora significativa na qualidade da água quando comparações foram feitas entre os períodos antes e depois da instalação das áreas de preservação. Os pontos de amostragem classificados como "bons" (CONAMA e WQI), que indicam água de boa qualidade e adequada para usos múltiplos, aumentaram de 52,0\% para $72,0 \%$. Nesse sentido, promover a preservação de cabeceiras e zonas ribeirinhas passa a ser de fundamental importância e destaca o papel do PSA como ferramenta operacional para a preservação dos recursos hídricos.

Palavras-chave: Bacia Hidrográfica do Arroio Andreas, pagamento por serviços ambientais (PSA), qualidade da água.

\section{INTRODUCTION}

In Brazil, water is considered an abundant natural resource compared to the current demand, although there are dry areas where water is used only for human needs. Although Brazil holds $8 \%$ of all freshwater in the world, the situation in the country is delicate. Most of the available volume (80\%) is in the Amazon region, and the remaining $20 \%$ is unevenly divided among the other regions in which $95 \%$ of the population lives (UNEP; IETEC, 2001). In the South, there are water shortages despite the large rivers and flow. These shortages are due to the cumulative effects of environmental processes and a broad spectrum of multiple water use in agriculture, industry, fisheries, navigation and recreation (Tundisi, 2000). Additionally, the quality of the small amount of available freshwater is degraded, mainly due to the rapid population growth observed in recent decades. This growth has generated a growing number of polluting processes that significantly alter the ecological balance of ecosystems, highlighting cultural eutrophication as one of the biggest problems for surface water and one of the most visible examples of the changes caused by humans to the biosphere (Smith and Schindler, 2009).

According to Esteves (2011), eutrophication is the concentration of nutrients, particularly nitrogen and phosphorus species or derivatives, in aquatic ecosystems; one result of eutrophication is increased productivity of biomass and decreasing of dissolved oxygen content, and thus the death of living biomass and biodegradation intensification. Eutrophication is a global problem that produces a marked deterioration of rivers, reservoirs, lakes and coastal 
waters and causes direct and indirect effects on biodiversity. Additionally, eutrophication jeopardizes the multiple uses of surface and groundwater resources, causing substantial losses to the local and regional economy. Eutrophication is a threat to public health and the general functioning of aquatic systems and is an important economic factor that can prevent or delay sustainable development (Tundisi, 2000; 2003; 2006 and 2007).

Among the complementary alternatives to local-sustainable development, payment for the provision of environmental services (PES) has been highlighted as a recent and innovative policy for environmental conservation. PES is defined as the voluntary transfer of funds from beneficiaries of such environmental services to those who perform them for the proper management of the ecosystem where these environmental services are being provided (Wunder et al., 2008). Because PES is a relatively new concept and practice, governments have only recently begun to recognize the role that farmers and users in rural areas can have on the improvement of environmental management. Tools for payment or compensation suggest that through incentives there will be a change in the behavior of economic agents in relation to the environment. According to the United Nations (ONU, 2011), the following environmental services are included in PES: the conservation and natural treatment of water resources, the preservation and conservation of biodiversity, soil erosion protection, carbon sequestration in the growth stage of the plant, regulating the local climate, besides the landscape formation and composition.

Based on these antecedents, the University of Santa Cruz do Sul (UNISC), in partnership with the Universal Leaf Tobacco Company and Fundación Altadis (non-profit organization, part of the Imperial Tobacco Group) signed a contract in 2011 for the execution of the project "Payment for Environmental Services" (PES) in the "Hydrographical Basin of Andreas Stream, county of Vera Cruz, RS, Brazil." The project, "Water Guardian," was to be developed over a period of five years (2011-2015) with the goal to protect the headwaters and the riparian areas of this basin and ensure the preservation of water resources by paying smallholder farmers for providing the environmental service to protect the headwaters located in their properties.

In this context, this study evaluated the effectiveness of the implementation of these conservation areas in the basin of Andreas Stream, RS, from July 2012 to June 2014, using environmental monitoring programs to assess physical, chemical, and microbiological variables.

\section{MATERIALS AND METHODS}

\subsection{Field of study}

The Hydrographical Basin of Andreas Stream, RS, is of fundamental importance as the source of water for the city of Vera Cruz. The soil relief map shows variations and terrain altitudes ranging between 500 and $100 \mathrm{~m}$. Land use is characterized by agriculture, including the cultivation of rice. It has an area of $80.2 \mathrm{~km}^{2}$ with a $21 \mathrm{~km}$ extension, with a population of 11,183 inhabitants in the urban area and 2,964 inhabitants in the rural area (IBGE, 2010). Along this basin, 20 sampling points have been selected (Figure 1) to carry out environmental monitoring studies in the rural properties that have joined the "Water Guardian" project.

\subsection{Collection/analysis of samples}

Monthly scientific expeditions were carried out from July 2012 to June 2014 in the 20 sampling points distributed along the Andreas Basin stream to measure physical, chemical and microbiological variables; a monthly sample was collected at each point during the period. The study period was divided into two stages: from July 2012 to June 2013, during which the conservation areas around the sampling points were being installed; and from July 2013 to June 2014, during which the areas of preservation around the sampling points were installed. 


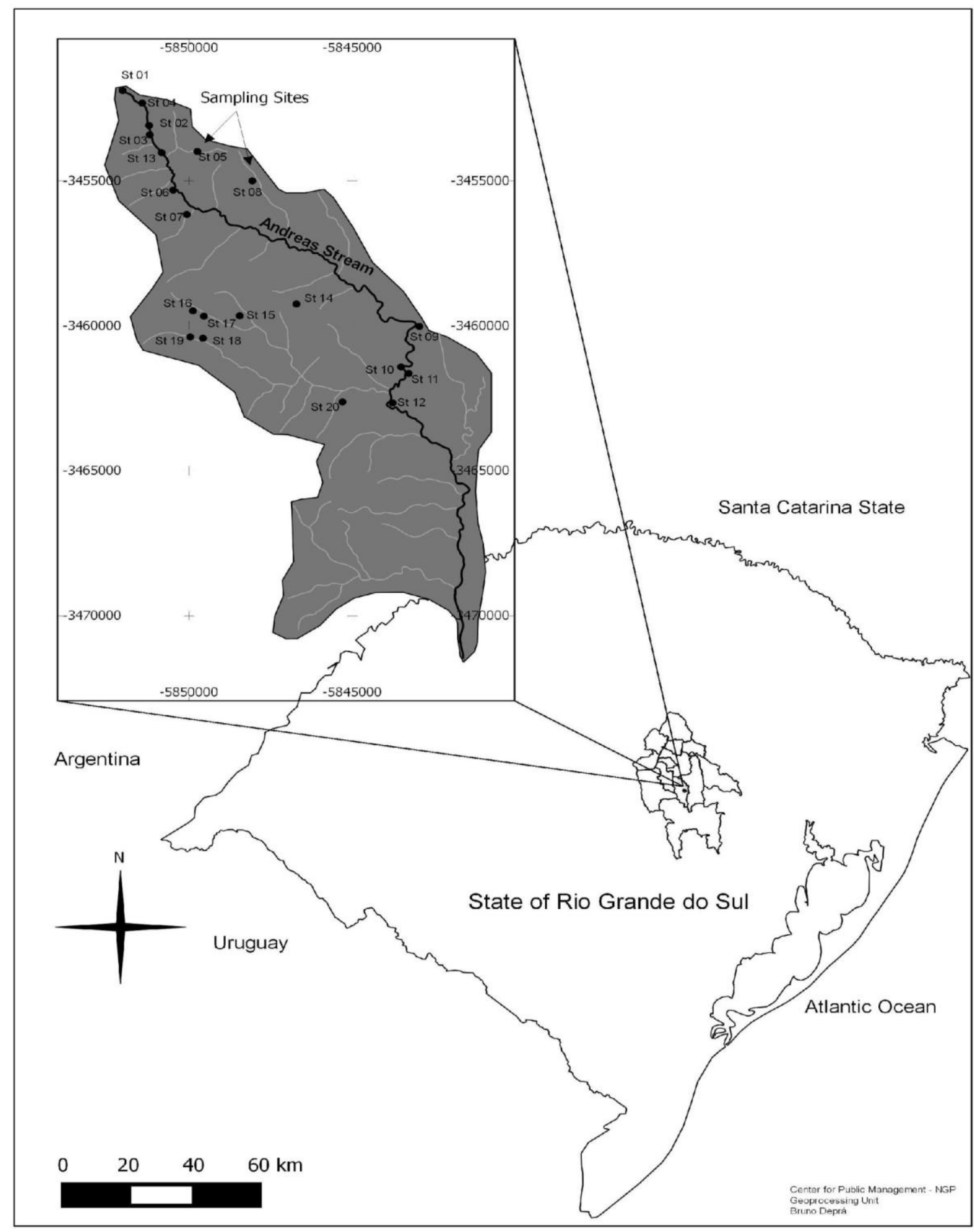

Figure 1. Map of the study area showing the location of Hydrographical Basin of Andreas Stream in the state of Rio Grande do Sul, highlighting the selected sampling points.

The following variables were considered as environmental evaluation parameters: temperature, $\mathrm{pH}$, turbidity, dissolved oxygen, biochemical oxygen demand after five days, nitrate, nitrite, total ammonia nitrogen, phosphate, total dissolved solids and thermotolerant coliforms. The samples were collected on the water surface using 300-1000 ml glass bottles packed in a Styrofoam box containing ice and the samples were analyzed the day after collection. The techniques used in sample collection and analytical determination of the physical, chemical and microbiological variables are described in APHA (2005). 


\subsection{Water Quality Assessment}

Based on the environmental analysis, the assessment of water quality was determined by Resolution Number 357 of the National Environmental Council (CONAMA), 2005 (CONAMA, 2005), which classifies fresh water into five different classes depending on the uses for which it is intended. The assessment of water quality was also made using the Water Quality Index (WQI) originally developed by the National Sanitation Foundation (NFS, 2007) of the United States and adapted for Brazilian waters by COMITESINOS (1993). To use the WQI in southern Brazilian river systems, Moretto et al. (2012) conducted a calibration of the weights of the variables used in the WQI formulation, checking for a significant correlation between the new calibrated weights and resolution 357/2005 of CONAMA (2005). The WQI calculations were made using the IQAData program developed by Posselt and Costa (2010). This software allows for both the application of the original NSF model or the development of new quality models, such as the calibrated WQI proposed by Moretto et al. (2012).

To operationally compare the water-use classes of CONAMA related to the quality requirements set by the IQA, a relative scale of agreement was used (Table 1). The scale reflects the main objective of the "Water Guardian" project, which is to achieve good water quality in the preserved areas, providing water that is suitable for multiple uses (human consumption after simplified treatment, protection of aquatic communities and primary contact recreation), a condition that characterizes the water-use Classes 1 and 2 of CONAMA (2005).

Table 1. Relative scale of agreement between the water use classes of CONAMA and the quality levels of the IQA.

\begin{tabular}{cc}
\hline Classes of use of CONAMA 357/2005 & Quality levels \\
\hline Special & Excellent \\
Class 1 & Good \\
Class 2 & Good \\
Class 3 & Regular \\
Class 4 & Poor/very poor \\
\hline
\end{tabular}

\section{RESULTS AND DISCUSSION}

The results of water quality evaluation in the 20 sampling points distributed along the Andreas stream from July 2012 to June 2013, (Table 2), (before installation of the protected areas), using Resolution 357/2005 of CONAMA (2005), are shown in Figure 2. Among the 220 sampling points, $32.0 \%$ were evaluated as "Class 1," $29.0 \%$ as "Class 2," $22.0 \%$ as "Class 3," and $17.0 \%$ as "Class $4 . "$

Table 2. Results of physico-chemical and biological analyses 2012-2013.

\begin{tabular}{lcc}
\hline Quality indicator & Average & Standard deviation \\
\hline Dissolved oxygen, $\mathrm{mg} \mathrm{O}_{2} / \mathrm{L}$ & 6,887 & 0,437 \\
$\mathrm{pH}$ & 6,876 & 0,903 \\
Temperature water, ${ }^{\circ} \mathrm{C}$ & 18,496 & 2,163 \\
Turbidity, FTU & 23,592 & 13,938 \\
Nitrate, $\mathrm{mg} / \mathrm{L} \mathrm{NO}{ }_{3-}$ & 1,351 & 0,723 \\
Thermotolerant coliforms, $\mathrm{NMP} / 100 \mathrm{~mL}$ & 2273,926 & 7740,408 \\
BOD-biochemical oxygen demand, $\mathrm{mg} \mathrm{O}_{2} / \mathrm{L}$ & 4,181 & 0,846 \\
Phosphate, mg/L $\left(\mathrm{PO}_{4}\right)_{3-}$ & 0,119 & 0,108 \\
Total ammonia nitrogen, $\mathrm{mg} / \mathrm{L} \mathrm{NH} \mathrm{N}_{3}$ & 163,452 & 0,565 \\
Nitrite, mg/L $\mathrm{NO}_{2-}$ & 174,425 & 0,017 \\
Total dissolved solids, $\mathrm{mg} / \mathrm{L}$ & 114,512 & 28,007 \\
\hline
\end{tabular}




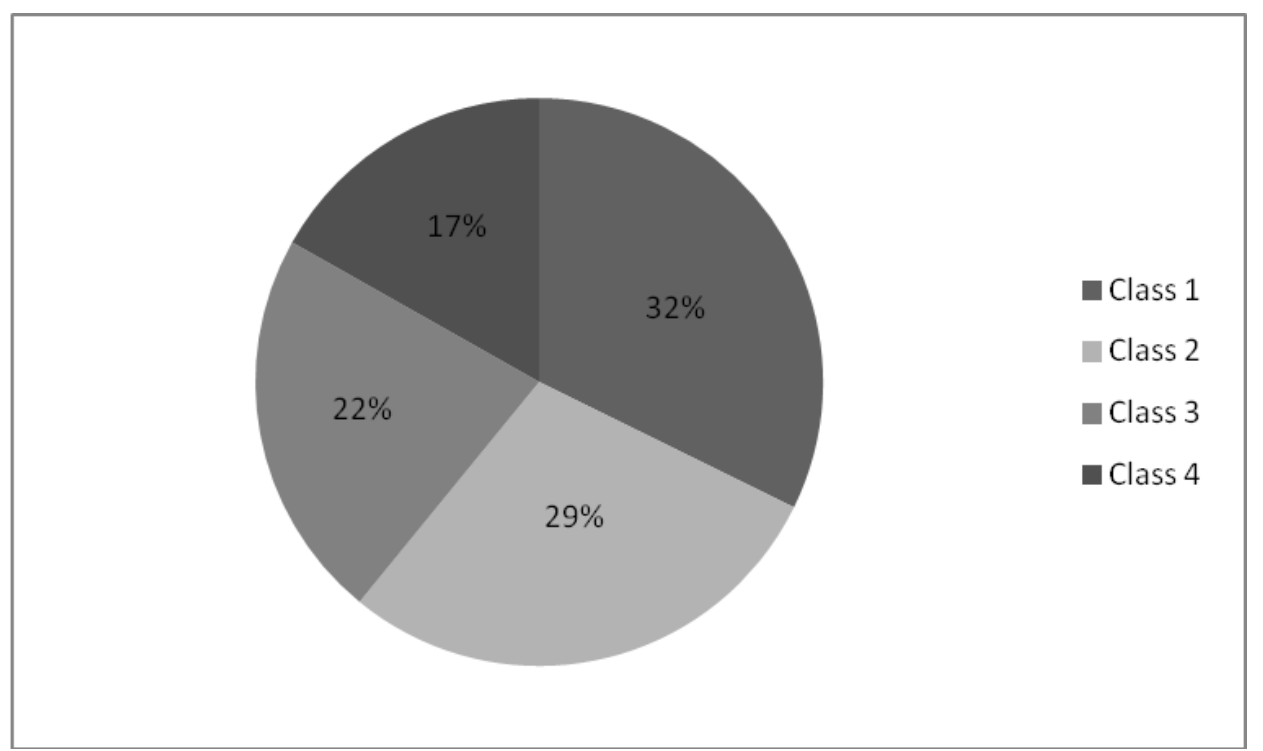

Figure 2. Classification of the 220 sampling points according to the decree 357/2005 of CONAMA (points P1 to P20), from July 2012 to June 2013.

The sampling points classified as Class 1 of CONAMA $(32.0 \%)$ are characterized as having good water quality that is appropriate for human consumption after simple treatment, the protection of aquatic communities and primary contact recreation (bathing), as its main features (CONAMA, 2005). The sampling points classified as Class 2 of CONAMA (29.0\%) also correspond to good quality water; the main difference compared to Class 1 is that Class 2 water can be used for human consumption only after conventional treatment (CONAMA, 2005).

The sampling points classified as Class 3 of CONAMA $(22.0 \%)$ have much more restrictive uses for their water than Class 2; for example, human consumption after conventional or advanced treatment, secondary contact for recreation and for cattle. Finally, the sample points classified as belonging to Class 4 of CONAMA (17.0\%) correspond to a class of lower quality water intended only for navigation and landscape harmony (CONAMA, 2005).

The results of evaluation using the Water Quality Index (WQI) adapted to the conditions in southern Brazilian by Moretto et al. (2012) in the 20 sampling points distributed along the basin of Andreas stream, RS, from July 2012 to June 2013 (before installation of the conservation areas), are shown in Figure 3. Among the 220 sampling points, $52.0 \%$ were classified as "good," $46.0 \%$ as "Regular" and $2.0 \%$ as "Poor."

Overall, during the period prior to the installation of the conservation areas, the results of the application of WQI indicated that $52.0 \%$ of the 220 samples collected were classified as "good," which corresponds to the $61 \%$ of Class 1 and 2 samples of CONAMA, indicating that these sampling points are characterized by good water quality that is appropriate for multiple uses. For the critical sampling points that showed water quality lower than the desired standards, the results of the application of WQI indicated that $48.0 \%$ of the 220 samples collected were classified as "Fair" or "Poor," values that correspond to the $39.0 \%$ of samples classified as Classes 3 and 4 of CONAMA, indicating that these sampling points have far more restrictive uses. 


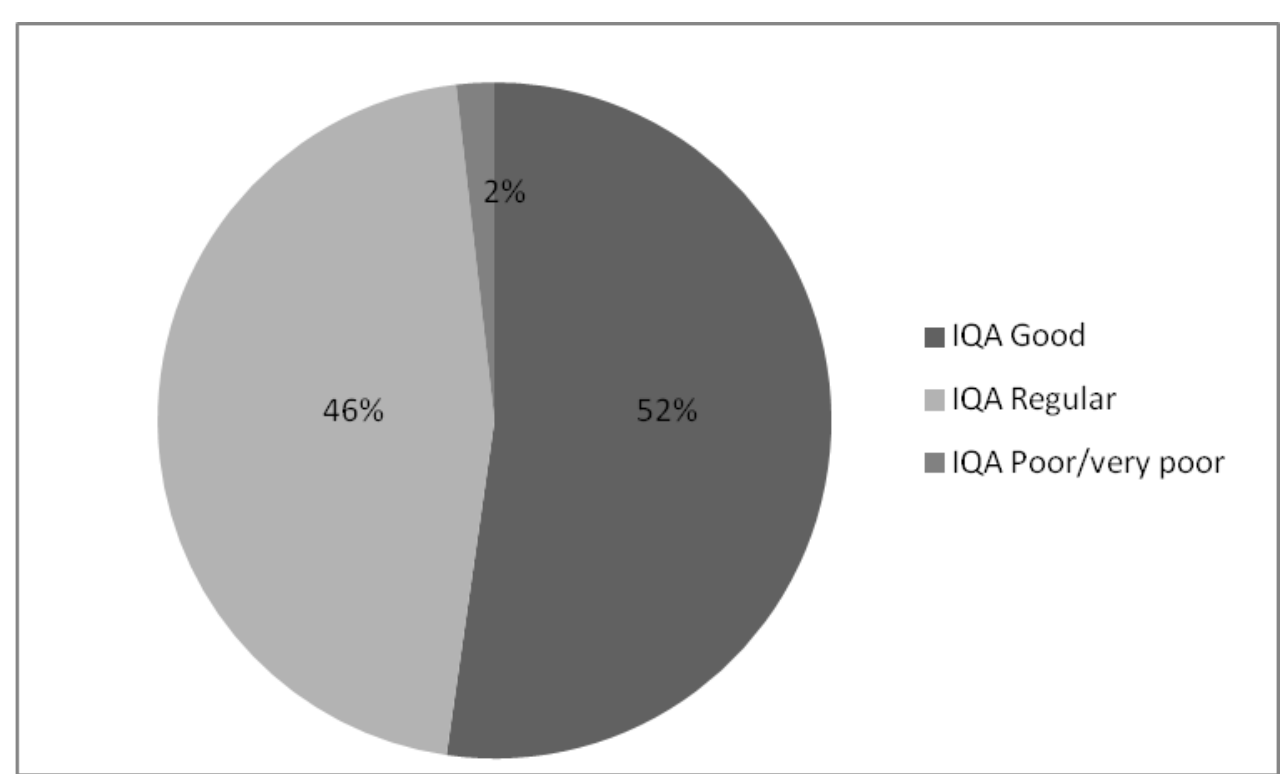

Figure 3. Rating of sampling points according to the WQI (points P1 to P20), from July 2012 to June 2013.

From July 2013, the installation of conservation areas in the 20 sampling points distributed along the Andreas stream was completed, and then a new sampling campaign started, according to results of the (Table 3). The results of the water quality evaluation, using the Resolution 357/2005 of CONAMA (2005), from July 2013 to June 2014 are shown in Figure 4. Among the 240 sampling points, $49.0 \%$ were classified as "Class 1," $24.0 \%$ as "Class 2," $15.0 \%$ as "Class 3," and 12.0\% as "Class 4". The results of the WQI are shown in Figure 5. Among the 240 sampling points, $72.0 \%$ were classified as "Good" and $28.0 \%$ as "Regular."

Table 3. Results of physico-chemical and biological analyses 2013-2014.

\begin{tabular}{lcc}
\hline Quality indicator & Average & Standard deviation \\
\hline Dissolved oxygen, $\mathrm{mg} \mathrm{O}_{2} / \mathrm{L}$ & 8,695 & 0,952 \\
$\mathrm{pH}$ & 6,919 & 0,036 \\
Temperature water, ${ }^{\circ} \mathrm{C}$ & 19,561 & 0,531 \\
Turbidity, FTU & 13,638 & 2,628 \\
Nitrate, $\mathrm{mg} / \mathrm{L} \mathrm{NO}{ }_{3-}$ & 1,023 & 0,235 \\
Thermotolerant coliforms, NMP/100 mL & 744,891 & 851,480 \\
BOD-biochemical oxygen demand, $\mathrm{mg} \mathrm{O}_{2} / \mathrm{L}$ & 2,334 & 1,455 \\
Phosphate, mg/L $\left(\mathrm{PO}_{4}\right)_{3-}$ & 0,069 & 0,126 \\
Total ammonia nitrogen, mg / $\mathrm{L} \mathrm{NH}_{3}$ & 0,510 & 0,258 \\
Nitrite, mg/L NO & 0,033 & 0,005 \\
Total dissolved solids, mg/L & 100,489 & 11,286 \\
\hline
\end{tabular}




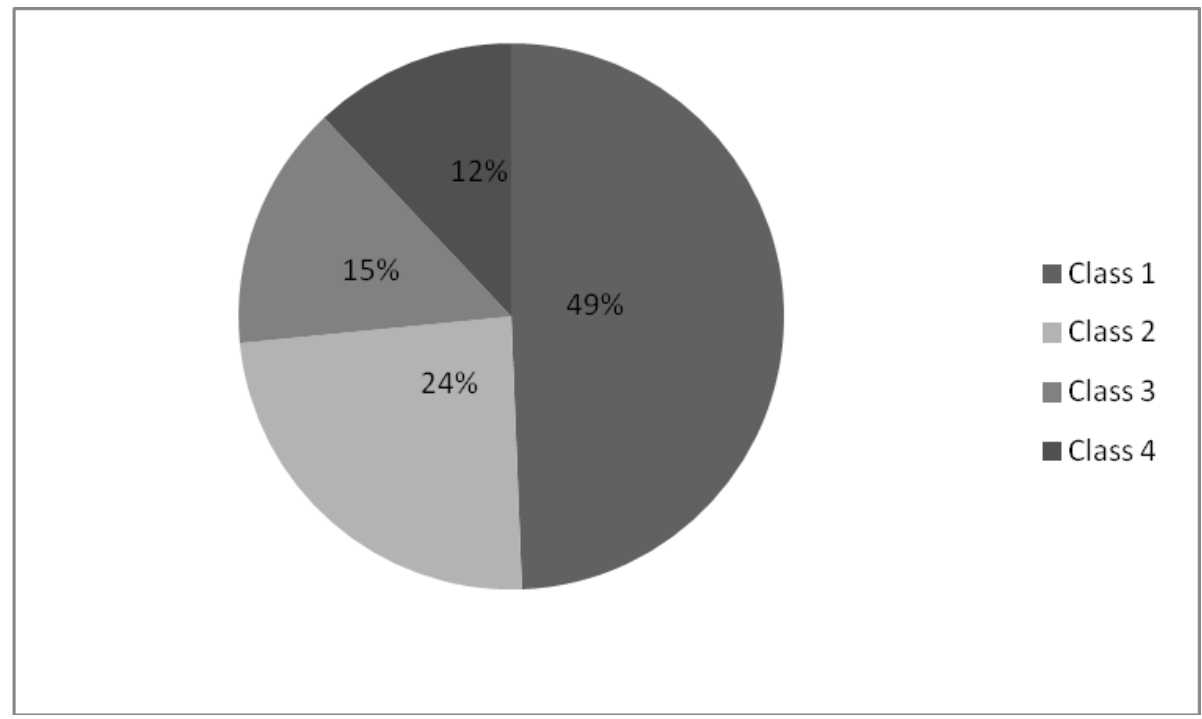

Figure 4. Classification of the 240 sampling points according to the decree 357/2005 of CONAMA (points P1 to P20), from July 2013 to June 2014.

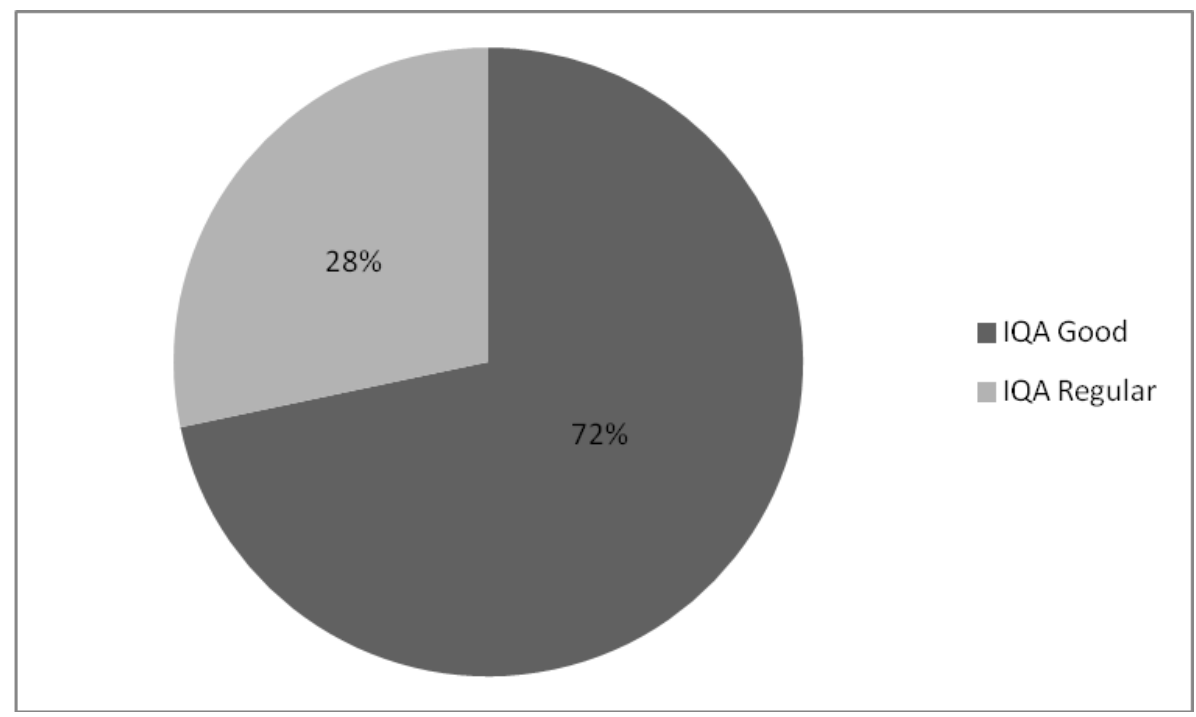

Figure 5. Rating of sampling points according to the WQI (points P1 to P20), from July 2013 to June 2014.

The results of the application of WQI after the installation of the conservation areas indicated that $72.0 \%$ of the 240 samples collected were classified as "good," which corresponds to the $73.0 \%$ of samples belonging to Classes 1 and 2 of CONAMA. The results indicated that $28.0 \%$ of the critical sampling points were classified "Regular," which corresponds to the $27.0 \%$ of samples belonging to classes 3 and 4 of CONAMA.

Comparing the results of the WQI with those of Resolution CONAMA 357/2005, small differences, $9.0 \%$ and $2.6 \%$, respectively, were found in the percentages separating sampling points appropriate for the noble uses of water (level "good" or Classes 1 and 2) from the critical sampling points (levels "Regular or Bad" or Classes 3 and 4) in the period before the installation of the conservation areas, whereas $1 \%$ differences were found in both cases in the period after the installation of the conservation areas. These differences could be explained by the differences in evaluation methods; when applying the CONAMA resolution in any point of collection, the value of the variable with the worst performance will be responsible for the final framing of this sampling point, while the WQI is calculated by the weighted multiplier of the 
corresponding water quality for each parameter evaluated, from the weights of importance of the nine variables used to set the index. The WQI is, therefore, a holistic index that characterizes the overall condition of a sampling point from the interaction of the nine variables that comprise the index. The WQI used was modified by Moretto et al. (2012) for their application in the Brazilian southern river systems. Thus, this WQI constitutes an effective technological tool to be used in environmental monitoring programs in Brazilian southern river systems, and it also provides significant information about the general environmental condition of a sampling point, complementing the results from the implementation of Resolution 357/2005 of CONAMA.

Overall, the results indicated that there was a significant improvement of water quality from the physical, chemical and microbiological points of view, comparing the periods before and after the installation of the preservation areas. We can actually see the results comparing Table 2 with Table 3, which demonstrates that the parameters obtained a significant improvement. There was a $38.5 \%$ increase of sampling points classified as having "good" water quality (CONAMA Classes 1 and 2), represented by increases from 52.0\% to 72.0\%, indicating that these sampling points are characterized as having good water quality suitable for multiple uses. Concomitantly, it was found that there was a $39.1 \%$ reduction of sampling points classified as "Regular" (CONAMA Class 3), represented by decreases from $46.0 \%$ to $28 \%$. Additionally, in the period after installation of the conservation areas, there was no sampling point ranked as "Poor" (CONAMA Class 4) compared to the previous period, when $2 \%$ of the sampling points were determined to be in this condition.

Although the reductions of the number of sampling points classified as "Regular" was evident, these points are critical, because the uses for the water in these points is more restrictive than for the water in sampling points classified as Class 1 and 2. These results could be explained by considering that these areas, even though protected, are still subject to the impact of a series of local human activities, such as the supply of nutrients and organic load from domestic sewage, cattle raising and the excess of fertilizers and agricultural inputs used in crops.

These environmental impacts can be evaluated from the variables responsible for the classification of the $28.0 \%$ of the samples as "Regular" (CONAMA Class 3), namely, the biochemical oxygen demand, dissolved oxygen, phosphorus, turbidity, nitrate and coliform. Thus, according to these variables, it is concluded that organic contamination and eutrophication of the water are the main environmental problems that characterized these water bodies. These results corroborate the environmental monitoring work in the regional water systems performed by UNISC, which has demonstrated that these water systems already have advanced stages of eutrophication (Bes et al., 2012; Böhm et al., 2013; Düpont et al., 2007; Hermany et al., 2006; Lobo et al., 2004a, 2004b, 2004c, 2004d, 2010, 2014; Oliveira et al., 2001; Salomoni et al., 2006; 2011; Schuch et al., 2012; 2014; Wetzel et al., 2002). According to Tundisi (2006), this condition characterizes in a general way all the waterways throughout the southern region of Brazil, according to the results obtained by the project "Brazil Waters."

\section{CONCLUSION}

The results clearly show that the preservation of water resources in headwaters and riparian zones plays an important role in water quality because the forests develop naturally and act as a protection zone in addition to being a source of food and protection for wildlife (Felfili et al., 2000). It is essential to recognize the importance of the environmental services provided by riparian forests and their influence on soil conditions, biodiversity, hydrological cycle and climate (Franco, 2010). Thus, promoting the recovery of degraded areas, especially those that are part of the permanent protection areas along rivers and springs, is of fundamental importance and highlights the role of the Payment for Environmental Services (PES) as an operational tool in the preservation of water resources (Tundisi et al., 2007).

\section{IPABH}

Rev. Ambient. Água vol. 14 n. 2, e2307 - Taubaté 2019 
Currently in Brazil, there is a number of projects aimed at water resource preservation that utilize PES, such as the project "Production of Water" in the basin of Pipiripau stream, DF. This project verified a $74 \%$ reduction of the costs of water treatment and a reduction of approximately $70 \%$ in water pollution by mercury and pesticides (Melo, 2013). There are other ongoing projects, such as the River Basin Benavente, ES, which is expected to expand to the entire state (ANA, 2014). In the basin of the Cantareira system, there are also PES experiences in Ribeirões do Moinho in Nazaré Paulista, SP, and Cancã in Joanópolis, SP (Melo, 2013). Finally, the Secretary of State for the Environment in Rio de Janeiro launched a River Parks Program aimed at the preservation of water resources by planting millions of trees on the banks of the Guandu and Macacu Rivers (INEA, 2014).

\section{ACKNOWLEDGEMENTS}

The authors thank CAPES/FAPERGS (Higher Education Personnel Training Coordination/Rio Grande do Sul Research Foundation) for the scholarship grant to the first author to pursue graduate studies. We like to thank CNPq for financial support through the Edict MCT/CNPq/Universal $n^{\circ}$ 14/2011. Also thanks are due to Universal Leaf Tobacco Company and Fundación Altadis, for financial support to the project "Water Guardian" in the period 2011/2015.

\section{REFERENCES}

ANA (Brasil). Produtor de água. 2014. Available in: http://produtordeagua.ana.gov.br/. Access in: 22 Dec. 2014.

APHA Standard methods for the examination of water and wastewater. 21. ed. Washington, 2005.

BES, D.; LUC, E.; TORGAN, L. C.; LOBO, E. A. Composition of the epilithic diatom flora from a subtropical river, Southern Brazil. Iheringia Série Botânica, v. 67, n. 1, p. 93$125,2012$.

BÖHM, J. S.; SCHUCH, M.; DÜPONT, A.; LOBO, E. A. Response of Epilithic Diatom Communities to Downstream Nutrient Increases in Castelhano Stream, Venâncio Aires City, RS, Brazil. Journal of Environmental Protection, v. 4, p. 20-26, 2013. http://dx.doi.org/10.4236/jep.2013.411A1003

COMITESINOS. Programa integrado de monitoramento da qualidade da água do rio dos Sinos e seus afluentes. Aplicação de um índice de qualidade da água no rio dos Sinos: período de novembro/1989 a outubro/1991. Porto Alegre, 1993. 38 p.

CONAMA. Resolução $n^{\circ}$. 357, de 17 de março de 2005. Diário Oficial [da] União, Brasília, n. 53, p. 58-63, 18 Mar. 2005.

DÜPONT, A.; LOBO, E. A.; BEM da COSTA, A.; SCHUCH, M. Avaliação da Qualidade da Água do Arroio do Couto, Santa Cruz do Sul, RS, Brasil. Caderno de Pesquisa Série Biologia, v. 19, n. 1, p. 56-74, 2007.

ESTEVES, F. A. Fundamentos de Limnologia. 3. ed. Rio de Janeiro: Interciência LTDA, 2011.

FELFILI, J. M. et al. Recuperação de matas de galeria. Brasília, 2000. p. 45. (Embrapa Cerrado Série Técnica, 21). 
FRANCO, J. G. O. Direito ambiental, matas ciliares: conteúdo jurídico e biodiversidade. Curitiba: Juruá, 2010.

HERMANY, G.; SCHWARZBOLD, A.; LOBO, E. A.; OLIVEIRA, M. A. Ecology of the epilithic diatom community in a low-order stream system of the Guaíba hydrographical region: subsidies to the environmental monitoring of southern Brazilian aquatic systems. Acta Limnologica Brasiliensia, v. 1, n. 18, p. 9-27, 2006.

IBGE. Censo 2010. Available in: http://cidades.ibge.gov.br/xtras/temas.php?lang=\&codmun= 432270\&idtema=16\&search=rio-grande-do-sul|vera-cruz|sintese-das-informacoes .

Access: 10 Dec. 2014.

INEA (RJ). Elaboração do Plano Estadual de Recursos Hídricos do Estado do Rio de Janeiro: R9 - metas e estratégias de implementação dos cenários propostos (versão final). Rio de Janeiro: Fundação COPPETEC: Laboratório de Hidrologia e Estudos de Meio Ambiente, 2014. 258 p. Available in: http://www.inea.rj.gov.br/cs/groups/public/documents/document/zwew/mdyy/ edisp/in ea0062140.pdf.Access: 14 Feb. 2017.

LOBO, E. A.; CAlleGARO, V. L. M.; HeRMANY, G.; BES, D.; WeTZEL, C. E., OLIVEIRA, M. A. Use of epilithic diatoms as bioindicator from lotic systems in southern Brazil, with special emphasis on eutrophication. Acta Limnologica Brasiliensia, v. 16, n. 1, p. 25-40, 2004a.

LOBO, E. A.; CALLEGARO, V. L. M.; HERMANY, G.; GOMEZ, N.; ECTOR, L. Review of the use of microalgae in South America for monitoring rivers, with special reference to diatoms. Vie et Milieu, v. 53, n. 2/3, p. 35-45, 2004 b.

LOBO, E. A.; BES, D.; TUDESQUE, L.; ECTOR, L. Water quality assessment of the Pardinho River, RS, Brazil, using epilithic diatom assemblages and faecal coliforms as biological indicators. Vie et Milieu, v. 53, n. 2/3, p. 46-53, $2004 \mathrm{c}$.

LOBO, E. A; CALLEGARO, V. L.; WETZEL, C. E.; HERMANY, G.; BES, D. Water quality study of Condor and Capivara streams, Porto Alegre municipal district, RS, Brazil, using epilithic diatoms biocenoses as bioindicators. Oceanological and Hydrobiological Studies, v. 33, n. 2, p. 77-93, 2004d.

LOBO, E. A.; WETZEL, C. E.; ECTOR, L.; KATOH, K.; BLANCO, S.; MAYAMA, S. Response of epilithic diatom community to environmental gradients in subtropical temperate Brazilian rivers. Limnetica, v. 29, n. 2, p. 323-340, 2010.

LOBO, E. A.; SCHUCH, M.; HEINRICH, C. G.; COSTA, A, B.; DÜPONT, A.; WETZEL, C. E.; ECTOR, L. Development of the Trophic Water Quality Index (TWQI) for subtropical temperate Brazilian lotic systems. Environmental and Monitoring Assessment, 2014. https://doi.org/10.1007/s10661-015-4586-3

MELO, J. P. F. O Projeto Produtor de Água no Pipiripau (DF) e o pagamento por serviços ambientais. 2013. Dissertação (Mestrado Profissional em Saúde Pública) - FIOCRUZ, Brasília, 2013.

MORETTO, D. L.; PANTA, E.; COSTA, A. B.; LOBO, E. A. Calibration of Water Quality Index (WQI) based on Resolution $n^{\circ} 357 / 2005$ of the Environment National Council (CONAMA) Brazil. Acta Limnologica Brasiliensia, v. 24, n. 1, p. 29-42, 2012.

NSF. Water Quality Index (WQI). 2007. Available in: http://www.nsf.org/consumer/earth_day/wqi.asp. Access in: 11 June 2007. 
OLIVEIRA, M. A.; TORGAN, L.; LOBO, E. A.; SCHWARZBOLD, A. Association of epiphytic diatom species on artificial substrate in lotic environments in the Arroio Sampaio basin, RS, Brazil: relationships with abiotic variables. Revista Brasileira de Biologia, v. 4, n. 61, p. 523-540, 2001.

ONU. Relatório-Síntese da Avaliação Ecossistêmica do Milênio. 2011. Available in: http://www.millenniumassessment.org/documentsdocument.446.aspx.pdf. Access in: 22 Dec. 2014.

POSSELT, E. L.; COESTA, A. B. Software IQAData 2010. Programa (Mestrado em Sistemas e Processos Industriais) - Universidade de Santa Cruz do Sul, Santa Cruz do Sul, 2010.

SALOMONI, S. E.; ROCHA, O.; CALLEGARO, V. L. M.; LOBO, E. A. Epilithic diatoms as indicators of water quality in the Gravataí river, Rio Grande do Sul, Brazil. Hydrobiologia, v. 559, p. 233-246, 2006. https://doi.org/10.1007/s10750-005-9012-3

SALOMONI, S. E.; ROCHA, O., HERMANY, G.; LOBO, E. A. Application of water quality biological indices using diatoms as bioindicators in Gravataí River, RS, Brazil. Brazilian Journal of Biology, v. 71, n. 4, p. 949-959, 2011. http://dx.doi.org/10.1590/S151969842011000500015

SCHUCH, M.; ABREU JÚNIOR, E.; LOBO, E. A. Water quality of urban streams, Santa Cruz do Sul, Rio Grande do Sul, based on physical, chemical and biological analyses. Bioikos, v. 26, n. 1, p. 3-12, 2012.

SCHUCH, M.; OLIVEIRA, M. A.; LOBO, E. A. Spatial Response of Epilithic Diatom Communities to Downstream Nutrient Increases. Water Environment Research, v. 87, n. 6, p. 547-558, 2014. https://doi.org/10.2175/106143014X14062131178196

SMITH, V. H.; SCHINDLER, D. W. Eutrophication science: where do we go from here?

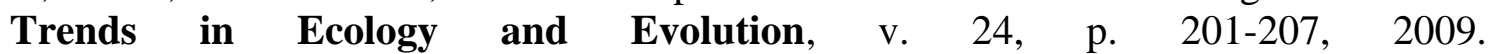
https://doi.org/10.1016/j.tree.2008.11.009

TUNDISI, J. G. Limnologia e gerenciamento de recursos hídricos: avanços conceituais e metodológicos. Ciência e Ambiente, v. 21, p. 9-20, 2000.

TUNDISI, J. G. Água no século XXI: enfrentando a escassez. São Carlos: RiMa, 2003.

TUNDISI, J. G. O Futuro dos Recursos Hídricos no Brasil. Projeto Brasil das Águas. 2006. http://www.brasildasaguas.com.br. Access in: 15 Dec. 2006.

TUNDISI, J. G. et al. Uso atual e potencial do solo no município de São Carlos, SP - base do planejamento urbano e rural. São Carlos: Instituto Internacional de Ecologia, 2007. (FAPESP - Políticas Públicas - Processo 98/10924-3).

WETZEL, C. E.; LOBO, E. A.; OLIVEIRA, M. A.; BES, D.; HERMANY, G. Diatomáceas epilíticas relacionadas a fatores ambientais em diferentes trechos dos rios Pardo e Pardinho, Bacia Hidrográfica do Rio Pardo, RS, Brasil: Resultados preliminares. Caderno de Pesquisa Série Biologia, v. 14, n. 2, p. 17-38, 2002.

WUNDER, S.; BORNER, J.; TITO, M. R.; PEREIRA, L. Pagamentos por Serviços Ambientais: Perspectivas para a Amazônia Legal. Brasília: MMA, 2008. 136p.

UNEP; IETEC. Planejamento e gerenciamento de lagos e reservatórios: uma abordagem integrada ao problema da eutrofização. Belo Horizonte, 2001. 385p. 